\title{
Constitución e historia en Ríos Rosas. Pensamiento y evolución de un hombre de Estado
}

\author{
Ángeles LARIO \\ Universidad Nacional de Educación a Distancia \\ alario@geo.uned.es
}

Recibido: $22 / 11 / 2011$

Aceptado: 05/07/2012

\section{RESUMEN}

Ríos Rosas comenzó su vida político-constitucional en 1836, cuando se produjo el cambio del modelo revolucionario de 1812 hacia el modelo post-revolucionario, parlamentario, moderado. Fue diputado nacional por primera vez en la citada fecha y pronto llegó a ser miembro del Consejo Real. Durante el reinado de Isabel II se opuso tanto a Espartero como a Narváez, apoyando una política civilista, como jurista notable que fue. Capaz de evolucionar mucho políticamente, acabó enfrentándose a Cánovas en el Sexenio.

Palabras clave: Biografía política, Parlamentarismo, civilismo, hombre de Estado.

\section{Constitution and History in Rios Rosas. Thought and Evolution of a Statesman}

\begin{abstract}
Ríos Rosas began his political and constitutional life in 1836, when the 1812 revolutionary political model transformed into the liberal post-revolutionary parliamentary moderate model. It was National Deputy for the first time on that date; soon becoming a member of the Royal Council, and during the Isabel II time, he opposed both Espartero as Narváez. He was a remarkable lawyer, civil, capable of evolve politically. Rios Rosas came to confront politically Cánovas in the "Sexenio".
\end{abstract}

Key words: Political biography, parlamentarism, civil, statesman.

Sumario: Introducción. 1. La Constitución y la Historia. 2. El intento de una revolución propia. El primer camino inglés y la "constitución histórica". 3. La presencia de la historia en la Cortes de Cádiz. 4. La Constitución y la Historia en Ríos Rosas. La soberanía nacional. 5. Ríos Rosas y la Monarquía. 


\section{Introducción}

Ríos Rosas ${ }^{1}$ comenzó su vida político-constitucional en 1836, con ocasión de la transformación del modelo político de 1812, en el momento en que se producía el cambio del modelo revolucionario liberal al modelo post-revolucionario, parlamentario, moderado, de convivencia política entre diferentes opciones. Fue Diputado nacional por primera vez en la citada fecha por la provincia de Málaga, llegando a ser pronto miembro del Consejo Real, ya con Isabel II. Él se opuso tanto a Espartero como a Narváez y quizá habría que destacar esto como fundamental en su modo de ver la política, civilista siempre, legal, no en vano fue jurista notable, capaz de evolucionar políticamente mucho, tanto que llegó a enfrentarse a Cánovas ${ }^{2}$ en el sexenio, quedando éste último en una posición considerablemente más conservadora, más pacata, que nuestro político liberal.

Sus intervenciones parlamentarias más significativas para lo que nos ocupa se produjeron en dos momentos constituyentes: el del Bienio y el del Sexenio. En ambos casos desde una posición privilegiada, como miembro de las Comisiones Constituyentes que se formaron en ambos casos, como era habitual, para elaborar la nueva Constitución. Es lo que llamaríamos un padre constituyente. Padre de dos de las Constituciones que se elaboraron en el XIX y que sirven para explicarnos nuestro modelo liberal, las batallas políticas, la cultura política de nuestro liberalismo, sus preocupaciones y debilidades.

La razón de hablar en Ríos Rosas de Constitución e Historia es que el de la historia un factor principal en la evolución de nuestro liberalismo, y la idea de "constitución histórica" lo fue especialmente en el liberalismo moderado y conservador. La cuestión de si se debía tener en cuenta, o no, la historia, las tradiciones, el consentimiento de generaciones pasadas, fue en lo que se apoyaron los llamados liberales moderados, para justificar su postura a favor del control, la limitación del principio de la soberanía nacional que les pareció peligroso aplicarlo literalmente sin otra consideración que el principio mismo de voluntad nacional inmediata. En su lugar optaron por defender la nación constituida, en la que el poder lo ejercían de modo compartido las instituciones, especialmente Corona y Cortes.

\section{La Constitución y la Historia}

Hay que comenzar distinguiendo los diversos significados de "Constitución" que aquí se utilizan. En línea con la imprescindible corriente historiográfica de historia de los conceptos, especifico que, evidentemente, estos pensadores y políticos

\footnotetext{
1 Antonio de los Ríos Rosas (Ronda, Málaga, 16 de marzo de 1812 - Madrid, 3 de noviembre de 1873), jurista y político español. Con la mayoría de edad de Isabel II, fue nombrado miembro del Consejo Real. Fue nombrado Ministro de Gobernación el 14 de julio de 1856 en el primer gobierno unionista, aunque cesó en octubre del mismo año. Jurista de gran prestigio, en 1852 ingresa en la Real Academia de Jurisprudencia y Legislación

2 Cánovas nació el 8 de febrero de 1828 y murió el 8 de agosto de 1897; es 16 años más joven que Ríos Rosas, que cuenta en este momento con 57 años, frente a los 41 de Cánovas.
} 
no están manejando el término "Constitución”, con el sentido que para nosotros tiene hoy día, recogido en el artículo 16 de la Declaración de los Derechos Universales, y que explica nuestra contemporaneidad: la declaración de derechos y la separación de poderes que los garantiza. Por el contrario, en lo que aquí estudiamos, "Constitución" tiene todavía un sentido primigenio de construir una colectividad. Con esas premisas deben entenderse las siguientes explicaciones que nos acercan a la idea que de "Constitución histórica" nos dieron los moderados y conservadores españoles y que explica tanto de nuestra evolución liberal.

En Ríos Rosas todo gira alrededor del consentimiento, de la necesidad de contar tanto con el consentimiento de cada momento, como con el histórico para conseguir la estabilidad y la permanencia de la sociedad tal y como se había constituido en el nuevo régimen. En realidad lo mueve el miedo a la soberanía en constante acción, el peligro de un estado perpetuo de Convención -este momento de la revolución francesa tuvo un peso determinante en la evolución del liberalismo-. Por ello cree inexcusable la existencia de un poder superior, limitador, controlador de los posibles excesos de la soberanía en acción, para mantener los principios básicos del sistema: libertad, propiedad, igualdad. Ese poder lo encuentra en una institución histórica, el Rey, como había hecho ya Benjamin Constant, que además diseñó su posición constitucional.

En Ríos Rosas se suma la utilidad institucional a la del significado de permanencia de la comunidad construida desde antiguo. Jovellanos, aproximadamente a partir de la década de 1790 ya había identificado "Constitución" con las Leyes Fundamentales españolas que determinaban la organización del Estado. Los propios constituyentes gaditanos aseguraron que su labor era renovar la legislación histórica española de acuerdo a las necesidades y las luces del momento ${ }^{3}$.

La mezcla de Constitución e Historia nos podría llevar hasta el final del siglo XI, según las fechas que manejaban nuestros constituyentes y el fundador de la historia del Derecho español, Martínez Marina ${ }^{4}$, en su afán de buscar antecedentes, tradición de gobierno constitucional antes de la revolución, tanto para avalar ésta (en un paralelo interesante a lo que hizo Locke con la revolución inglesa), como para no tener que buscar referencias en el caso francés, enemigo con el que se estaba batallando a la par que se hacía la Constitución. Tanto Martínez Marina como los constituyentes gaditanos recuerdan el pasado de constitución mixta,

3 Para la influencia del pensamiento español en nuestra contemporaneidad puede verse: Ignacio FERNÁNDEZ SARASOLA, Poder y libertad. Los orígenes de la responsabilidad del Ejecutivo en España (1808-1823), Madrid, Centro de Estudios Políticos y Constitucionales, 2001. También: La Constitución española de 1812 y su proyección europea e iberoamericana, Alicante, Biblioteca Virtual Miguel de Cervantes, 2004. Clara ÁLVAREZ ALONSO, "Un Rey, una Ley, una Religión (goticismo y constitución histórica en el debate constitucional gaditano", Historia Constitucional. Revista electrónica, no 1 (junio 2000).

4 Francisco Xavier Martínez Marina (Oviedo, 1754-Zaragoza, 1833) fue un jurista, historiador y sacerdote español. Padre fundador de la historia del derecho español. Fue el primero que estudió la formación de nuestros códigos. Mantuvo una opinión similar a Jovellanos y los jovellanistas sobre la Constitución de Cádiz: la de que existía previamente una «constitución» tradicional, apropiada a los usos y costumbres españoles. Diputado por Asturias en el Trienio, formó parte de la Comisión legislativa que dio lugar al Código Penal de 1822. Con el absolutismo se le envió a Zaragoza donde murió. Su Discurso sobre el origen de la Monarquía y sobre la naturaleza del gobierno Español (1813) puede verse en la Biblioteca Virtual Cervantes: http://www. cervantesvirtual.com/servlet/SirveObras/57960620216137506322202/index.htm 
de monarquía electiva, de "buena constitución" desde los godos, como ya había visto James Harrington, y luego reconoció también Guizot ${ }^{5}$.

Martínez Marina buscó en la legislación histórica española y su Monarquía desde los godos, reeditada más tarde, los rasgos del constitucionalismo moderno: separación de poderes, derecho legal y garantía de los derechos de los ciudadanos virtuosos y sabios.

Es un dato de interés que en las Cortes leonesas de 1188 convocadas por Alfonso IX, las primeras europeas donde participa el tercer Estado y cuyo modelo se incorporó después a Castilla, Aragón e Inglaterra, y el resto de Europa, se reconoce la inviolabilidad del domicilio, del correo, la necesidad del rey de convocar Cortes para hacer la guerra o declarar la paz, y se garantizan numerosos derechos individuales y colectivos. De tal modo que se podía encontrar en ese gobierno la respuesta a las exigencias de una doctrina política que desde por lo menos mediados del XVII venia reivindicando reiterada e insistentemente un cambio constitucional, basado precisamente en tales premisas, como jamás dejaron de divulgar y recordar sus máximos representantes.

Este afán de buscar en la historia los elementos necesarios para la propia revolución española, es propio casi de todos los procesos revolucionarios, especialmente el inglés, que también aspiró a recuperar para sus ciudadanos derechos olvidados por los reyes que pretendían ser absolutos. Es, en definitiva, el salto sobre el absolutismo para retomar lo mejor de las tradiciones anteriores.

Este afán existió en Cádiz también; en todas las discusiones constituyentes estuvo presente esa constitución histórica que tuvo gran fuerza en Jovellanos en conexión constante con Lord Holland y el espíritu político inglés. Jovellanos decía en la $\mathrm{Me}$ moria en Defensa de la Junta Central, hablando de la convocatoria de Cortes, que "Creía que ella sola podía salvarla (a la patria), y que, después de salvarla, ella sola podía restablecer y mejorar nuestra constitución, violada y destruida por el despotismo y el tiempo; reducir y perfeccionar nuestra embrollada legislación, para asegurar con ella la libertad política y civil de los ciudadanos"6. Luego se recuperó esta idea durante la estabilización de la revolución por pensadores y políticos que incidieron más en esa faceta de nuestra política, de nuestra cultura política. Uno de esos políticos fue Ríos Rosas, como luego lo fue Cánovas.

\section{El intento de una revolución propia. El primer camino inglés y la "constitu- ción histórica"}

Vejamos a Inglaterra, esse governo sempre citado, sempre imitado por quasi todos os povos que querem ser livres. E todavia as fórmas exteriores de civilidade, e cumprimento, são tão excessivamente monarchicas, que muitas vezes repugnam a nossos

\footnotetext{
5 James Harrington escribió La república de Oceana en 1656 tras el fin de la Monarquía de Carlos I, François Guizot, Historia de los orígenes del gobierno representativo..., 1851, recogido por Clara ÁLVAREZ ALONSO, ob. cit., pfs. 13, 14 y 15. (Lección 26, pp. 461-462; Lección 25, pp. 435 y ss. Introductores de la igualdad ante la ley (p. 441).

6 Su Memoria en defensa de la Junta Central puede consultarse en la Biblioteca Virtual Cervantes: http:// www.cervantesvirtual.com/servlet/SirveObras/12048065338088290754624/p0000001.htm\#I_2_
} 
ouvidos ciosos, e recusariam nossas bocas livres pronuncia-las. Mas o equilibrio é perfeito. A corôa respeitada, e rodeada de cortejos e homenagens, é todavia impotente para mal fazer". Diario de Sesiones de la Sesión Extraordinaria de 1837. Lisboa. Sr. Almeida Garrett, 24 de Abril de 1837

La cita podría reproducirse de casi cualquiera de los diferentes procesos constituyentes, en el siglo XIX y en el XX, en sistemas monárquicos y republicanos (como el mexicano de 1917 o el caso italiano de 1946-4777), y así quedaría más que evidenciado el modelo inglés "sempre imitado" como referencia en la construcción del Estado contemporáneo.

La referencia al camino inglés, como no podía ser menos, alude al modelo moderado de gobierno parlamentario que había nacido y se estaba desarrollando en la monarquía inglesa tras su revolución del XVII ${ }^{8}$. En España, los primeros intentos de inclinar la balanza en un sentido "parlamentario", se encuentran en los mismos momentos en que se gesta la revolución política, en medio de la guerra contra los franceses. La influencia inglesa fue evidente en estos primeros momentos en Jovellanos, principal protagonista en la Junta Central en 1809-10. ${ }^{10}$.

En Jovellanos la solución política pasaba por la tradición española de Cortes con Rey, y por ello veía en el caso inglés, que partió de los mismos principios en su revolución del XVII frente al absolutismo, el modelo a seguir. Sin embargo, Adolfo Posada advierte que "de haber realizado los legisladores de Cádiz una restauración o resurrección -artificial tenía que ser- de las formas y fórmulas políticas tradicionales, anteriores al absolutismo monárquico, la Constitución de 1812 habría galvanizado una España vieja mucho más artificiosa y de prestado...". Pero quizá haya que poner ciertos reparos a este eminente autor porque no reconoce en los ingleses lo que ellos mismos sostuvieron como justificación de su revolución, esto es, que con ella volvían a los antiguos fueros y libertades de los gobernados. Por ello, a la par que admira a los ingleses, niega a "los Jovellanos" la bondad de su resolución para seguir el mismo camino". Todavía en la España revolucionaria y en el caso de Jovellanos, imitar lo inglés era seguir su mismo camino para hacer una revolución propia, lo que, como sabemos, se vio alterado por la forma y las circunstancias en que fueron convocadas las Cortes de Cádiz, aunque no impidió una fuerte presencia de la historia y la tradición española en las discusiones constituyentes.

\footnotetext{
7 Para el caso italiano, por ejemplo NITTI el 23 de octubre de 1947: "Nel Paese da cui vengono le forme costituzionali, l'Inghilterra,...", en Archivio Storico. Camera dei Deputati: La Costituzione della Repubblica nei lavori preparatori della Assemblea Costituente (AS,CD).

8 VARELA SUANZES, J., "Sistema de Gobierno y partidos políticos en el pensamiento constitucional británico durante el último tercio del siglo XVIII (de Blackstone a Paley)”, en Revista Electrónica de Historia Constitucional, $\mathrm{n}^{\mathrm{o}} 1,2000$.

9 LARIO, Ángeles, "Del liberalismo revolucionario al liberalismo post-revolucionario en España. El triunfo final del camino inglés Espacio, Tiempo y Forma, V, n 17 (2006). Id., "el modelo liberal español", en Revista de Estudios Políticos, n' 122 (2003). Id., "La Monarquía del Liberalismo a la Democracia", en Ángeles LARIO (ed.), Monarquía y República en la España Contemporánea, Madrid, UNED- Biblioteca Nueva, 2007, pp. 42 y 22.

10 Lo muestra MORENO ALONSO, La forja del Liberalismo en España. Los amigos españoles de Lord Holland 1793-1840. Madrid, Congreso de los Diputados, 1997. p. 116.

11 POSADA, A., La reforma constitucional, Madrid, 1931, pp. 63-64.
} 
Jovellanos personifica en España y en el momento de la revolución este primer camino inglés, con el "esfuerzo realmente asombroso para contener los avances revolucionarios", y "su preocupación e insistencia por dejar acabado... un sistema moderado de gobierno... una copia del sistema constitucional inglés" ${ }^{12}$. Era un terreno abonado, por otra parte, pues se produce en un contexto de guerra contra Francia, a lo que hay que sumar la merma de su influjo tras la Revolución y las guerras de la Convención de 1893 (ya Feijoo recogía que hasta los franceses reconocían "la ventaja del espíritu filosófico ingles"). Rodríguez Aranda dejó reflejada la huella de Locke "desde Feijoo a Jovellanos o desde Martínez Marina a Quintana". El propio Godoy en sus Memorias se atribuye la introducción de Locke y Newton en las cátedras españolas. Si nos adelantamos más en el tiempo, al estudiar a los constitucionalistas del XIX y los discursos de los políticos de la Restauración, se percibe igualmente de un modo claro que el constitucionalismo inglés, es "punto de referencia fundamental para todo el liberalismo europeo"13. Ciertamente, en las discusiones de los constituyentes franceses de 1789, Inglaterra está presente constantemente, pero en muchos casos para recordar los defectos de su sistema; mayoritariamente se reconoce su aportación a la libertad y la superioridad de su espíritu público, asentado ya desde hacía mucho tiempo; pero eso les sirve para defender que las leyes francesas deban ser más perfectas para compensar esa diferencia ${ }^{14}$.

El camino inglés implica convivencia entre los poderes, y por ello no se olvida Holland de señalar a sus amigos españoles la equivocación de Montesquieu, que difundió el modelo inglés por el continente, cuando creyó ver en él una separación estricta de poderes; efectivamente, dice, la Cámara de los Comunes, "por el derecho que goza de disponer de los medios y arbitrios, pudiera ganar toda la máquina del Estado si se empeñara en hacerlo", pero el equilibrio procedía del influjo "real y efectivo que la Corona y la Cámara de los Pares tienen en (ella)" 15 .

Por ello, en el momento de la convocatoria de Cortes se trató de convocarlas al modo antiguo, en tres brazos; pero ya en enero de 1810 se pensó en dos Cámaras, aunque ampliando el número de electores municipales y "añadiendo otros tantos representantes libremente elegidos por el vecindario", que fueran únicamente electores y no elegibles. En ese proyecto, las Cortes debían estar presididas por la Regencia, y las leyes debían ser aprobadas por ambas Cámaras y sancionadas por la Regencia, que también podía disolver las Cortes ${ }^{16}$ : esta era la materialización de la idea de Jovellanos de que las Cortes deberían quedar "acomodadas a las luces del siglo y a

12 ARTOLA, M., La España de Fernando VII, Espasa Calpe, Madrid, 1999, p. 323. Sobre el sentido de reforma de las Leyes Fundamentales en Jovellanos, y su admiración por la "excelente constitución inglesa": FERNÁNDEZ SARASOLA, I., Poder y libertad: los orígenes de la responsabilidad del Ejecutivo en España (1808-1823), Madrid, Centro de Estudios Políticos y Constitucionales, 2001; especialmente p. 303-306.

13 MORENO ALONSO, La forja del Liberalismo, cit., p. 49. LARIO, A., El Rey, piloto sin brújula, Madrid, Biblioteca Nueva, 1999, capítulo I.

14 Rabaud de Saint-Etienne, el 4 de septiembre de 1789. Id. Gregoire. Id. Alexandre de Lameth (cita, p.ej. a De Lolme). Id. Mirabeau el 1 de septiembre: "los ingleses lo han hecho todo". Sobre la necesidad de superar a los ingleses en las leyes: M. De Castellane, 3 de septiembre: Archives Parlamentaires. Asemblée nationale. Paris (APP.AN).

15 MORENO ALONSO, ob. cit., pp. 262-263. Puede verse también SÁNCHEZ GARCÍA, R., Alcalá Galiano y el liberalismo español, Madrid, CEPyC, 2005, "la formación de un liberal", pp. 64-66.

16 ARTOLA, op. cit., 319-320, 323. 
los muchos mandamientos que se han hecho desde el siglo dieciséis, y muy aumentadas en el número de sus vocales". A esa búsqueda en el armario de la historia de los elementos necesarios para componer una nueva figura, se le ha denominado con extraordinario éxito "invención de la tradición", pero ya Jovellanos había hablado de "acomodación" a la actualidad de elementos preexistentes.

En Jovellanos -o el propio Alcalá Galiano-, el conocimiento del proceso revolucionario francés, y las reflexiones sobre el mismo de Burke que según Javier Varela ${ }^{17}$ ya conocía en 1795, consagran su horror a la ruptura violenta. Pero no pudo escapar de la contradicción de situarse en medio de una tendencia reformista que, a su vez, abría el camino a un proceso revolucionario. En la misma Inglaterra, siempre tomada como ejemplo de moderación y reformas paulatinas, decía Guizot que no se hubiera podido llegar a la revolución moderada de la Gloriosa de no haber pasado por la revolución radical de 1640-49, cuando se le cortó la cabeza al Rey, se llegó a la guerra civil, se llegó a la república y a la dictadura de Cromwell, recorriendo así todos los escalones de una revolución que ahora querían evitarse ${ }^{18}$.

En la revolución española, lo característico fue la transferencia de la soberanía, por la vía de los hechos, a nuevas instituciones surgidas del levantamiento popular, a que dio lugar la defensa frente a la invasión francesa de la que, inmediatamente, se denominará nación. Por ello no iba a resultar fácil mantener la soberanía del Rey ausente en medio de un proceso de defensa y constitución de la nación por las Cortes.

\section{La presencia de la historia en la Cortes de Cádiz}

Al contrario que en Francia, las discusiones constituyentes en Cádiz sí mostraron esa impronta histórica que defendía Jovellanos. Quizá como nunca en Cádiz se acomodó la tradición a las nuevas necesidades. La misma existencia de una comisión para recopilar y revisar las antiguas constituciones y fueros -donde destacó la figura ya venerable del catalán Antoni de Capmany-, constantemente manejadas y tenidas en cuenta por los constituyentes, las diferencia de las constituyentes francesas, donde si acaso alguna vez se menciona la tradición o legislación histórica ${ }^{19}$. En España esta permanencia de la Constitución histórica, de Cortes y Rey, garantizaba la legitimidad de la obra gaditana. Espiga deja bien claro el 27 de octubre de 1811 que "la comisión ha dicho que no ofrece en su proyecto cosa alguna que no esté consignada del modo más auténtico y solemne en nuestro antiguo gobierno". El tradicionalista Borrull, al presentar la nueva propuesta de organización de un presupuesto y control del mismo por las Cortes, dice que se trata de restablecer "los derechos que se reservaron los pueblos al tiempo de formar las Monarquías de Asturias y Sobrarbe, que constan por las leyes del Reino". Es tan puntillosa la documentación de nuestros constituyentes

17 VARELA, J., Jovellanos, Madrid, Alianza Universidad, 1988, p. 243

18 JOURDAN, cit., p. 303-304. LARIO, A., "La Monarquía Constitucional. Teoría y práctica política", en J. TUSELL, A. LARIO, F. PORTERO (eds), La Corona en la historia de España, Madrid, Biblioteca Nueva, 2003. pp. 106-111

19 Le comte de Lally-Tollendal -angómano citado por Constant-, del comité de la Constitución, el 31 de agosto de 1789, defiende la balanza y equilibrio de poderes en el clásico diseño de dos Cámaras y Rey. 
gaditanos que dan hasta el nombre de quien (el marqués Caballero) "con notoria temeridad y abandono de sus obligaciones" hizo "borrar de la memoria de las gentes" semejante antecedente, "mandando que no se insertasen en la Novísima Recopilación (1805), lo que no podrá suceder ahora que ha declarado V.M. (las Cortes de Cádiz) en el artículo 131 de la Constitución las facultades de las Cortes, y entre ellas la de establecer las contribuciones y aprobar el repartimiento de las mismas entre las provincias" ${ }^{20}$. El propio Flórez Estrada en su proyecto de Constitución de 1809, para justificar la necesidad de la misma, se remonta a "nuestros antepasados", empezando por el código gótico que "cuidó primeramente de dar leyes a los monarcas, de deslindar sus derechos y de prescribir sus obligaciones, aun antes que las de los súbditos" ${ }^{21}$.

Aún más, se busca la tradición del pensamiento español en el reconocimiento de los derechos del pueblo, sin necesidad de recurrir al pensamiento foráneo. Así lo hace Villanueva el 7 de octubre de 1811. Del mismo modo, En el discurso preliminar del 12, aludiendo al Fuero Juzgo (siglo XIII) se dice que "la soberanía de la nación está reconocida y proclamada del modo más auténtico y solemne en las leyes fundamentales de este código" 22 . De nuevo Argüelles recurre a la tradición en la conformación y denominación de instituciones, defendiendo el término de "Diputación" en lugar del de "legislatura", "que no es española", para referirse a "las dos reuniones de unos mismos Diputados en los dos años de su encargo" 23 .

Tanto deseo de mantener la tradición lleva a los constituyentes a dejar al margen de las discusiones de Cortes la religión católica y la Monarquía, principios que había sentado Quintana en línea con el pensamiento de Jovellanos. Respecto a la Monarquía, al contrario que con la religión, eso parecía inevitable, con sólo observar lo que sucedió en el resto de países occidentales. Los propios revolucionarios franceses, en el primer momento, en su primera Constitución, no la discutieron en absoluto. Bien al contrario, la discusión se centró sobre el carácter que debía tener su intervención en el legislativo: sanción o veto ${ }^{24}$. En cuanto a la religión, no hubo en España nada parecido a la "Constitución civil del clero" de Francia, ni a la libertad religiosa reconocida

20 Borrull el 11 de noviembre de 1811: Diario de Sesiones de las Cortes Generales y Extraordinarias (DSCGE).

21 Constitución para la Nación Española. Presentada a S.M. la Junta Suprema Gubernativa de España e Indias. En $1^{\circ}$ de noviembre de 1809. Por Álvaro Flórez Estrada. Procurador General del Principado de Asturias. Introducción. El significado de "constitución gótica", "Constitución histórica", "leyes fundamentales" en ÁlVAREZ ALONSO, C., "Un Rey, una ley, una Religión (Goticismo y constitución histórica en el debate constitucional gaditano)" en Historia Constitucional. Revista Electrónica ,n 1, junio 2000. Sobre Jovellanos, CORONAS GONZÁLEZ, S.M., "El pensamiento Constitucional de Jovellanos”, en Ibidem.

22 La autoridad (el Rey) "la recibe de sus mismos súbditos. Y esta doctrina no la hemos mendigado de extranjeros; la enseñan sabios teólogos y publicistas españoles de los mejores tiempos”, pp. 2010-2011.

23 "la Diputación es propia y peculiar de España, y no tiene ejemplo en ningún otro país en que se halla adoptado un gobierno representativo": Argüelles, Id., pp. 2013, 2007.

24 En palabras de Furet y Hálevy, eligieron entre conservar simplemente al Rey o establecer plenamente un gobierno monárquico. En realidad, la cuestión de la Monarquía fue el corazón de los debates y de las luchas hasta 1791, y es el que divide al campo revolucionario: FURET, F., HALÉVY, R., La Monarchie Républicaine. La Constitution de 1791. Fayard, 1996, pp. 13 y ss. p. 9 Debates de agosto y septiembre de 1789, centrando en ella todos los debates: APP.AN. Ciertamente perdieron los que proponían el veto absoluto, es decir, la propia comisión constituyente: Mounier, anglómano, en nombre de la comisión: 4 de septiembre, pp. 554-564. 
en Inglaterra o en los Estados Unidos ${ }^{25}$; aquí pesó decisivamente su consideración de Ley Fundamental, por la influencia del "goticismo" citado que implicaba la asunción de la religión como pilar de la Monarquía y la cohesión de la sociedad y, sobre todo, la necesidad de no romper la cohesión en un momento de guerra contra los invasores. Sin embargo, a pesar del artículo 12, como veremos, se inició el camino hacia la reforma: desde la abolición de la Inquisición el 22 de febrero de 1813, hasta la transformación de la situación económica de la Iglesia, que la hacía dependiente del Estado. De hecho, en la práctica, se buscaba la independencia Iglesia/Estado, pero la teoría, al menos de primera hora, no lo indicaba así ${ }^{26}$.

\section{La Constitución y la Historia en Ríos Rosas. La soberanía nacional}

\section{“QQué ha sucedido en España siempre?”27}

Ríos Rosas accedió por primera vez a las Cortes en 1836, como hemos dicho, justo cuando se llevó a cabo la primera Constitución post-revolucionaria que bien pudo ser modelo constitucional permanente en España con las subsiguientes reformas. Como no fue así tuvo ocasión de manifestarse contrario y hacérsenos evidente sus teorías políticas con ocasión de la reforma constitucional del Bienio. Después tuvo ocasión de participar más activamente al serle encargada la redacción del Acta Adicional para suavizar la Constitución de 1845. Antes se había opuesto dentro del grupo puritano a la reforma de 1837 en contra del Secretario de la Comisión de 1845, Donoso, que consideraba urgente la reforma, consagrándose en ese momento la división del partido Moderado triunfando el grupo de Narváez frente a los más constitucionales de Pacheco, Pastor Díaz y Ríos Rosas, los llamados puritanos -quedando todavía otro sector más a la derecha de los de Donoso, que eran los seguidores de Viluma que quería acercarse y contemporizar con los carlistas. En el Sexenio tuvo ocasión de enfrentarse con Cánovas, mostrándose más avanzado que el ilustre político conservador.

Seguidamente se analiza, porque es de sumo interés para el objeto de nuestro estudio, su posición en el Bienio Progresista (1854-1856).

Las Cortes Constituyentes fueron convocadas por Real Decreto de 11 de agosto de 1854, produciéndose la apertura regia el miércoles 8 de noviembre. El 27 de enero de 1855 comenzó la discusión de las bases constitucionales, dándose inicio precisamente por la base redactada por Ríos Rosas: "Toda potestad pública emana de la Nación"

25 JOURDAN, A., La Révolution, une exception française?, Paris, Flammarion, 2004, pp. $304-305$. PORTILLO VALDÉS, J.M., Revolución de nación. Orígenes de la cultura constitucional en España, 17801812, Madrid, CEPyC, 2000, cap. I.

26 Con ocasión de la composición del Consejo de Estado, Argüelles refutó la pretensión de que los Prelados eclesiásticos formaran parte del mismo: “... La religión tiene sus pastores establecidos por Dios, y hay una línea divisoria entre ella y el Estado; de manera que jamás se pueden confundir unos negocios con otros". Defendió también la inmunidad de los diputados en el tema religioso (junto con Muñoz Torrero y Villanueva ), y por ello se le tildó de hereje en algunos papeles y pasquines colgados por la ciudad, porque además pidió que los diezmos se pudieran utilizar para casos de necesidad pública.El ceremonial para la toma de posesión del 24 de septiembre de 1810 es ilustrativo del peso de la religión: DSCGE.

27 Ríos Rosas el 20 de mayo de 1869 en el Congreso 
frente al dictamen de la comisión que decía que "todos los poderes públicos emanan de la Nación, en la que reside esencialmente la soberanía, y por lo mismo pertenece exclusivamente a la Nación el derecho de establecer sus leyes fundamentales". Presenta este voto particular como miembro de la Comisión constituyente, junto con otros 27 individuos, y frente a la mayoría de esa comisión ${ }^{28}$.

El que responde a este voto particular es Sancho, miembro también de la comisión constituyente y eminente político que había fundamentado la Constitución de 1837. De tal modo que en estas fechas dice ser el más viejo diputado de estas Cortes. Es el que nos recuerda cuál había sido el dictamen. Y se sorprende de las contradicciones que surgen con el término y significado de "soberanía" porque mientras Ríos Rosas acepta que la potestad emana de la Nación, reconoce ante Sancho que siente repugnancia por la palabra "soberanía", así como por "toda exageración de principios"; por ello insiste en que ningún principio abstracto debe quedar escrito en las Constituciones. ${ }^{29}$. Todas estas precauciones, dice Ríos Rosas se deben a que todas las Constituciones se hacen después de una revolución y hay que precaver "la exageración de principios".

Curiosamente, Gil Sanz, defendiendo la completa capacidad de constituir de las nuevas Cortes, que no querían una mera reforma constitucional, dice que todos aquellos que se refieren a la Constitución de 1837 podrían hacerlo aún con más razones a la de 1812 que además de decididamente liberal "descuellan las tradiciones de nuestras antiguas Cortes", en referencia precisamente a la historia en nuestro proceso constituyente $^{30}$. Como sucede en toda la historia de nuestro liberalismo, la batalla se centra en torno al significado y amplitud de la soberanía nacional. Se recuerda que en 1837 quedó "vergonzosamente relegado en el encabezamiento" de la Constitución y "ahora se establece por la mayoría en uno de los primeros artículos". He aquí el núcleo de toda la batalla teórica de nuestro liberalismo. Lo reconoce así el propio Ríos Rosas cuando defiende el citado voto particular al proyecto constitucional. Dice que

"Entre todas estas cuestiones descuella por su inmensa importancia en el orden doctrinal, así como en el orden político, la que el dictamen de la Comsisión resuelve en su base $1^{\text {a }}$. El principio de la soberanía nacional, trascrito casi literalmente de la Constitución francesa de 1789 en la Constitución española de 1812; consignado dogmática y sobriamente en el preámbulo de la de 1837; refundido en la omnipotencia política de los altos Poderes del Estado en la de 1845, vuelve a aparecer ahora en el cuadro de nuestras instituciones expuesto en una forma rigurosamente preceptiva y desenvuelto en sus más graves y más problemáticas aplicaciones"

Claro, reconoce el hecho de que "la Nación española, como toda Nación independiente y libre, es dueña de sí misma y árbitra de su propia suerte" y por lo tanto rechaza abierta y decididamente "el principio bárbaro y feudal del derecho patrimonial

28 DSC, CC, 13 de enero de 1855, Voto particular de Ríos Rosas, pp. 1352-1354. Será rechazado el 1 de febrero por 214 votos frente a 18 entre los que se encuentran los de Cánovas, Moyano, Rancés, Castro, Nocedal, Camacho o Cantalejo.

29 DSCC, 1854-1855, Ríos Rosas el 27 y el 29 de enero de 1855. Cánovas el 29

30 Diario de Sesiones del Congreso, Cortes Constituyentes (DSC, CC), Gil Sanz, 23 de enero de 1855, tomo II. 
en la institución y en la transmisión de la Corona", así como "la doctrina impía del derecho divino en el origen, en el carácter y en las funciones de la autoridad Real hereditaria" que, dice son hechos "escritos en nuestra historia", un "axioma inmortal", una "verdad positiva" que "reside en las entrañas y se manifiesta en la estructura, en el pormenor y en el conjunto de todos nuestros antiguos Códigos de todas nuestras Constituciones modernas". Es decir, no sólo la revolución, no sólo 1808 y 1810 y 1812 han marcado esta característica de nuestra Constitución, equiparable a las Constituciones contemporáneas, sino que estaría ya en nuestra tradición, en nuestra historia, en nuestros más antiguos Códigos.

Es pues el principio de la soberanía nacional algo inherente que puede aparecer en "la primera página de la ley política del Estado" -en clara referencia a 1837- pero que ni es necesario ni bueno "acompañarle y envolverle y ahogarle con deducciones siempre disputadas en la región de la teoría, con prescripciones nunca triunfantes en el campo de la historia". Aquí aparece la necesidad inexcusable de contar con la historia, con la experiencia, con la comprobación de los hechos frente al voluntarismo de la teoría para establecer los principios rectores de la Constitución. Reconoce que esta advertencia es la razón fundamental de su voto particular, tal es la importancia que se da a esta batalla por la soberanía, su significado y sus posibles consecuencias. Disiente con la mayoría "en el modo de formular el principio de la soberanía" e insiste en que la soberanía es un principio teórico más propio de un libro que de una ley, queriendo dejarlo apartado de la Constitución. Por ello se preguntan los diputados que si es un mero principio teórico y por lo tanto inofensivo "por qué ese tenaz deseo de exluirle, por qué temerle?" y seguidamente contesta lógicamente que "es porque cada principio es el origen de una serie de leyes, y los que no están conformes con la soberanía del pueblo no pueden admitirla como principio ni dejar que se consigne, temerosos de que ha de irse desenvolviendo en leyes arregladas a su espíritu" ${ }^{31}$.

Y es que Ríos Rosas entiende que la soberanía nacional o significa sufragio universal o no significa nada -como recuerda Escosura el 30 de enero de 1855-, como insiste Cánovas el mismo día; es el gran argumento, puesto que no votan todos es una usurpación, sustituyen "al libre albedrío de la Nación una soberanía suya propia, hija de una oligarquía", y aún más explícito "decidnos, cuando venís aquí representando el voto de 400.000 electores en una Nación donde hay 5 millones que tienen capacidad de elegir"; la conclusión: "'claro es y evidente que hay aquí alguna cosa que no es la soberanía nacional tal y como la entendéis vosotros"; eso es el consentimiento, pero el Trono también es consentido, se mantiene por la voluntad "cada momento manifestada de todos los españoles" y que es por ello "una representación muy alta de la Nación, y por consiguiente de su soberanía" y si "lo era cuando existía, por el mero hecho de existir, y de existir tantos siglos", "nadie lo ha despojado, nadie ha querido despojarlo de esta representación merecida". Y define la mentalidad política: "creemos en la delegación coetánea, en la soberanía nacional del Trono con las Cortes, histórica, tradicional"; "el Trono con el pueblo es la verdadera soberanía nacional, la única práctica y aceptable", de lo que deduce, claro, que la Reina debe sancionar la Constitución. La clave para Ríos Rosas está en cambiar los términos:

31 Gil Sanz, op. cit. 
en lugar de hablar de poderes y soberanía prefiere hablar de potestad, y así reconoce que "la potestad (los poderes públicos) emana de la nación" sustituyendo lo de que "la soberanía reside esencialmente en la Nación" y separándose así "del voto de la mayoría". "potestas quiere decir poder y derecho para ejercerlo", dice el 29 de enero, explicando su voto.

En esta discusión se muestra la importancia de la Monarquía y el peligro que corría por estar siempre en boca de todos. Al fin es la garante de la sociedad establecida, frente a la Convención, a la soberanía nacional actuante sin límites. Efectivamente todo el argumento es para justificar el no hablar de soberanía que es, sin embargo, en palabras de Gil Sanz, el principio que acaba con el derecho divino, el principio que se enfrenta a la tiranía. Por eso la Constitución de 1845, a su entender, lo que hizo fue encubrir un "despotismo hipócrita" tras la máscara constitucional, porque no aceptaba ese principio. Ahí es donde, en esta interpretación que tendrá larga vida e incluso parece comprobada en la historia de España ${ }^{32}$, se coloca el mal uso de la Monarquía, colocado el Trono, se dice "por antemural de pasiones bastardas", "enfrente del pueblo", lo que explicaría que justo entonces, en el Bienio, llegase la primera discusión formal de la Monarquía en unas Cortes Constituyentes españolas ${ }^{33}$. Así lo refiere el propio Gil Sanz en contestación precisamente a Ríos Rosas, empeñado en no manejar el término de "soberanía nacional":

"El año 40 hubo un pronunciamiento, y nadie creyó posible ni pensó siquiera en nada que perjudicase al Trono, a la dinastía. / En el año 43 tampoco sufrieron ningún ataque esos objetos; tampoco existía partido que se ocupase de la cuestión monárquica. Desde entonces acá ese partido ha ido creciendo. ¿Quiénes han sido los que le han hecho crecer... los predicadores de esa doctrina? Han sido los mismos que con tanto entusiasmo hablaban del Trono; ellos fueron los que hicieron lo posible por desacreditarle, y necesaria fue toda la magnanimidad del pueblo para que conservase el Trono su anterior prestigio a beneficio del bautismo con que le rejuveneció la voluntad del país" 34

Del mismo modo, Ríos Rosas pretende mantener los cinco años de duración del Congreso que consignaba la Constitución de 1845, frente a la norma de tres años de la de 1837 que se pretende reponer en el Bienio. La razón que alega es el exceso de elecciones: "vais a tener, señores, probablemente, todos los años elecciones de Milicia, elecciones de Ayuntamientos, elecciones de Diputaciones provinciales, y vais a tener, a más tardar, cada dos años, el movimiento político de las listas electorales para Diputados a Cortes. Si teneis además cada tres años la agitación profunda y simultánea de una elección general en toda la Monarquía... la fiebre permanente a que vais a condenar a los pueblos". Pero aún más, añade ya algo más relevante como dato histórico, "la levadura de corrupción que han depositado en las ciudades y en los campos (la acción electoral de las últimas Administraciones); los gérmenes de malquerencia y de discordia que han derramado a manos llenas en todos los ámbitos

\footnotetext{
32 Véase LARIO, A. (ed), Monarquía y República en la España Contemporánea, Madrid, UNED / Biblioteca Nueva 2007

33 A. LARIO, "La Monarquía herida de muerte. El primer debate Monarquía / República en España", en A. LARIO (ed.), Monarquía y República en España, op. cit.

34 DSCC, 1854-1855, Gil Sanz el 23 de enero de 1855
} 
del Reino; el influjo mortal que han ejercido donde quiera en las costumbres públicas y privadas; la desconfianza, el escepticismo, el sentimiento de inestabilidad, el horror a las crisis políticas, aún las más pacíficas y normales, de que han imbuido a la sociedad entera" 35 .

Muestra de su posición más moderada en principios básicos, este voto particular sirve para disentir "profundamente" de la mayoría de la Comisión en otros temas también, pero siempre relacionados con la consecuencia de la "soberanía nacional", y así discrepa rotundamente de la reposición de la Diputación Permanente que se toma de 1812 y su capacidad de reunir Cortes en casos determinados sin "Real convocatoria", pues lo cree "incompatible con la autoridad Real", "contrarias al espíritu y al mecanismo del régimen monárquico-constitucioonal" en lo que se refiere a la necesaria concordia al respeto y la necesaria circunspección mutua de los poderes, y el culto a las formas, que quedaría roto con la previsión de futuros conflictos entre Ejecutivo y Legislativo y la creación entonces de lo que llama "doble Ejecutivo" por la capacidad de convocatoria de la Diputación, "que reduce forzosamente a la condición de enemigos al Poder Real y al Poder parlamentario".

Este voto particular es un extracto espléndido de su pensamiento, porque toca además la cuestión de los Alcaldes y Ayuntamientos tal y como establecía la base 20 del proyecto que califica de "absolutismo impaciente y duro". El proyecto prohibía al Rey cualquier intervención en ninguna localidad y desde luego en el nombramiento de alcaldes. Critica acerbamente que se establezca para su elección el sufragio directo universal "jamás usado entre nosotros" y "lo mismo en Madrid que en la más humilde aldea". El pide que el Rey pueda intervenir en el nombramiento de los alcaldes en los pueblos y el forma que determine la ley.

Conjugando, dice, este modo de elegir Ayuntamientos y la independencia absoluta de los Alcaldes, junto con otros influjos de otras instituciones que no menciona -pero puede ser la Milicia, por ejemplo- "la Nación española podrá venir a despojarse de hecho del carácter de Monarquía constitucional y se asemejará grandemente a una federación de Repúblicas". Es decir, si no hay un fuerte poder central representado por la Corona y se suma la autonomía local el resultado es la República. Aquí tenemos representada, en la mentalidad de la época, la diferencia entre Monarquía y República, el significado que tienen entonces ambas formas y que ya he tenido ocasión de recoger algunos estudios en la obra citada, con el interés que tiene para cualquier análisis histórico el conocimiento preciso de los conceptos utilizados, de la cultura política dominante. La Monarquía era el modelo que se consideraba preciso para grandes y antiguas naciones, unidas, constituidas de antiguo, históricamente, y que había que unificar legislativamente en la mentalidad de la revolución liberal que se estaba cuajando. La República era buena para unir colonias en una única nación, como había pasado en los Estados Unidos de Norteamérica, era precisa para federar, para conseguir la unión, era un modelo preciso para un caso concreto, para nuevas naciones, sin historia común. No se entendía, por tanto, que cualquier pensador o político bien formado pretendiera una República en una vieja nación.

35 DSCC, 1854-1855; Voto Particular de Ríos Rosas, 13 de enero de 1855. Apéndice II al n 57 
Añade que los republicanos saben lo que quieren y los monárquicos no, y ésta es una observación, es una crítica repetida de los Moderados a los Progresistas: les acusan de no conocer el verdadero significado de las cosas, de los términos, de los principios políticos; en resumidas cuentas, les acusan de no entender que aceptar la soberanía nacional es contrario a ser monárquico, porque se acepta la posibilidad de la República: "la mayoría de los monárquicos ya saben lo que quieren, y por eso no quieren ese dogma y no lo reconocen" ${ }^{36}$. Y trata de explicar por qué no acepta "la ley de las mayorías" que va implícito en la soberanía nacional. Fundamentalmente porque es una ficción "que lo que quieren los más lo quieren todos, que la mayoría es la unanimidad"; además es otra ficción, dice, ique todos los que emiten una opinión son igualmente capaces": " ¿se puede aplicar la ley de las mayorías a la universalidad de los ciudadanos en ningún país del mundo?... No, señores, esto no sería una ficción, sería una mentira y un absurdo; y sobre los absurdos y las mentiras no se edifican más que catástrofes", y acaba señalando esto, el sufragio universal que implica la soberanía nacional, como "el vicio fundamental" de ese principio, porque "el sufragio universal en una nación grande es una mentira, es una iniquidad, es una catástrofe". Debemos entender que para él, como para el resto de Moderados, el sufragio universal era prácticamente sinónimo de Convención (de paso sabemos que ante estas argumentaciones se reía Orense, marqués de Albaida).

Es de interés su asociación de soberanía nacional con las Asambleas únicas, propias del modelo revolucionario, con la tiranía que producen esos modelos -y pone el ejemplo del Parlamento largo inglés, la muerte de Carlos I y la dictadura de Cromwell; o la Asamblea francesa que acaba con la Monarquía y llega a la Convención; o la república de Florencia que desemboca en la dictadura de los Médici- que en visión histórica nos resulta de interés pues hoy tenemos otras formas en plena democracia. Él llega a la conclusión de que el sufragio universal lleva a la dictadura, y pone además el ejemplo de los Napoleón en Francia: "en el sufragio universal hay una fatalidad necesaria, como tiene que haberla siempre que predomina la acción del número, en la que es la fuerza numérica la fuerza bruta sobrepuesta a la de la inteligencia, de la capacidad y de la ciencia"; y para que no se crea que es sólo cosa de la "Europa cristiana" pone el ejemplo de Roma y la crisis entre la aristocracia y la democracia y la llegada de César votado de nuevo por la mayoría, como los Napoleón. En las votaciones populares, continúa, "no hay deliberación; no hay criterio; no hay más que un sentimiento ciego; no hay más que eso en el ejercicio de la soberanía nacional": sentimiento ciego como propio de la soberanía nacional, frente a deliberación y criterio de la soberanía que se dio en llamar de la inteligencia. Él mismo se reconoce, por sus palabras, como casi inventor del concepto, pero al negar la soberanía nacional, la de origen divino, la patrimonial, cree necesario especificar su principio político; y lo hace "combinando de buen fe la teoría y la práctica; examinando la historia de los pueblos, y cómo se funda el poder de la sociedad, y sobre todo viendo como se consolidad": El poder no puede ser sólo la fuerza sino el "asentimiento y el derecho", pues "para mandar... se necesita el consentimiento de los demás". Por ello coloca frente a la soberanía nacional el consentimiento; consentimiento que pasa por generaciones para estabilizar las

36 DSCC, op. cit., Ríos Rosas el 29 de enero de 1855 
situaciones (o sea que la mayoría no sabe lo que vota en el momento, y generaciones sucesivas consienten en algo que ya han olvidado o desconocen!!!!). Así pues hay dos consentimientos, el "primordial" que se necesita para crear el poder y obrar; y el consentimiento "actual" que se necesita para "la manera de ejercer el poder a fin de no caer en la usurpación o en la tiranía". Y no quiere hablar de pacto social por las consecuencias que de él se sacaron. Además sigue hablando de "súbditos" respecto al poder, añadiendo que es "la teoría de los Gobiernos representativos" que "exige la inspección, la intervención de los súbditos en el poder". Esa teoría, dice, la encuentra en "la narración constante de la historia". Por eso, dice, ha abandonado todos los conceptos de soberanía, "he seguido la historia para saber cómo se llega a formar un poder estable, nacional y liberal".

Claro que en 1869 Ríos Rosas también reniega de la soberanía como la entiende el doctrinarismo, que popularizó, dice, Coussin, una soberanía nacional "limitada por no sé qué de vago... oscuro... indefinido... por la soberanía del genio... de la inteligencia... de la razón.... De la virtud.... Por limitaciones arbitrarias e impracticables". Él prefiere otro sistema de soberanía limitada "muy superior a ese otro sistema... profundamente práctico y profundamente verdadero... la afirmación y la inviolabilidad de los derechos individuales". Vemos esa evolución constante de Ríos Rosas, y lo explica porque "El Estado es soberano, sí; pero los derechos individuales son anteriores, son superiores, son exteriores al Estado. El Estado no puede herir, no puede suprimir, no puede destruir los derechos individuales" ${ }^{37}$. Así pues descubre los derechos individuales como muro infranqueable, como algo superior a la propia soberanía nacional, con lo cual parece perder el miedo por fin a dicho principio.

Ríos Rosas muestra además en esta discusión, y ante los protagonistas de entonces que ya en 1837 los Progresistas limitaron la soberanía nacional. Observa y refleja ahora la transformación de la cultura política que significa la Constitución de 1837 $\mathrm{y}$, especialmente, en boca de políticos progresistas de tanto peso como era el propio Olózaga. Y allí, delante del propio político lo utiliza como referencia de esa matización de la soberanía. Olózaga, dice, "en la Constitución de 1837 no adoptó enteramente el principio de la soberanía nacional, tal como antes se había adoptado en la de $1812 " 38$. Pero más cuRíoso todavía, advierte de que los dos principales autores de la Constitución de 1837, Sancho y Olózaga, no están conformes. Sancho porque quiso poner la soberanía nacional dominándolo todo, y Olózaga porque entendió que una vez conseguido el triunfo frente a la opresión "en nombre de Dios", se entiende que

37 Diario de Sesiones. Congreso, legislatura 1869-1871 (DSC 1869-1871).Ríos Rosas el 20 de mayo de 1869

38 Ya dejé escrito que "Olózaga en esa coyuntura, justificó el término de veto absoluto -que tanto temía Argüelles-, por la necesidad de introducir la "soberanía a la inglesa" -la de los poderes constituidos-, aceptando el reparto del ejercicio de la soberanía y significando de hecho el reforzamiento del poder ejecutivo, de la Corona y su ámbito, es decir, del propio Gobierno de Gabinete": LARIO, A., "La Monarquía en España y la construcción del Estado Contemporáneo", en LANDAVAZO, M. A. (ed.), Experiencias monárquicas y republicanas en Hispanoamérica, siglos XIX y XX, México, Porrúa / Universidad Michoacana de San Nicolás de Hidalgo. 2009. “Con la ruptura de 1836 y tras la Constitución de 1837 se avanzó decididamente en el modelo parlamentario de Gobierno que el ejemplo inglés y su primera puesta en práctica en el continente (Francia, Bélgica) había dado ocasión de conocer y de valorar como el medio más práctico para una política estable y de orden dentro del Liberalismo.": LARIO, A., "El modelo liberal español", Revista de Estudios Políticos, $\mathrm{n}^{\circ} 122$ (2003) 
de la soberanía de derecho divino, el principio no debía estar dentro de la Constitución "porque parecía que estaba deshaciéndola continuamente, que estaba excitando a que se deshiciese" ${ }^{39}$. Es el típico argumento de la época, de la moderación: una vez lograda la revolución, el principio no funciona o, mejor, funciona en la base del sistema, en su propio origen, pero no debe ponerse en funcionamiento a no ser en un caso de extraordinaria necesidad, como ya se decía en 1812 y por lo que no apareció el artículo completo como había establecido entonces el proyecto: escribiendo la capacidad de darse la forma de gobierno que más conviniera. Se dijo que eso se sobreentendía pero no debía escribirse.

Olózaga, recuerda Ríos Rosas, era progresista, justo cuando "empezamos a dar a conocer y acreditar esta palabra, porque no nos agradaba la de exaltados, que nos habían regalado los del bando contrario" (en 1837), y quitó el principio de la parte dispositiva de la Constitución, "aceptó gustoso la eliminación de este principio, y lo rayó de la Constitución... y condescendió con nosotros en que se pusiera al frente de la Constitución de 1837”. Y como Olózaga otros progresistas, como Escosura, que quisieron ratificar esa postura política. Por eso pudo decir Ríos Rosas en 1855 que "convenía el partido progresista... en la teoría de que el principio de la soberanía nacional no era otra cosa más que una protesta contra la opresión" y por eso, continúa, "se deduce que el principio de la soberanía nacional es falso, es funesto, que no puede ser base de ningún orden de cosas, que no puede ser base de Gobierno ni de ninguna cosa estable... en lo humano no hay ni puede haber nada absoluto". Por eso, remata, "tan impíos son los que proclaman el derecho divino absoluto, como los que proclaman el derecho humano absoluto, ¡sí, tan impíos!".

Todo el argumento se basa en la necesidad de delegar el poder. Como no pueden concurrir todos los ciudadanos " un campo de Marte, a un campo de Mayo... a deliberar y votar su Constitución política”, la cuestión se centra en quién se delega; la pregunta es si sólo puede ser en una Asamblea única. La respuesta ya se aferra a la historia “¿Qué ha sucedido en España siempre?", un país, recuerda, "constituido de tantos siglos" volviendo a la idea de que "la libertad es antigua, el despotismo es moderno". Y lo que ha sucedido, y para eso sirve el recurso a la historia, es que "el Poder Real, de ordinario, interviniendo en la formación de las leyes, ha favorecido la libertad pública", pues "el derecho público de España ha sido siempre que el Rey ha intervenido directamente por sí en la formación de las leyes", y como en el 12 se recuerda la historia de Aragón "donde los Parlamentos eran más fuertes, legislaban a la par que el Rey y tenían la iniciativa", Cataluña, Navarra, Castilla "donde el poder de los Parlamentos era más limitado, legislaban por medio de peticiones", "en fin, en toda la península". Del mismo modo se recuerda al proceso de 1812, que sancionó la existencia histórica de la Monarquía en nuestra Constitución: "aquella Comisión, compuesta de varones tan doctos, tan ilustres, tan patriotas, a quienes debemos la libertad de nuestra Patria, a quienes debemos nuestra regeneración y nuestro porvenir... no pudieron menos de confesar que en todas nuestras Monarquías el Rey había tenido la potestad legislativa". Así es que "nadie podrá negar la teoría del Poder Real", que

39 DSCC, cit. Ríos Rosas el 29 de enero de 1855. Él mismo nos informa que desarrolló estas teorías en un discurso de la Academia de Jurisprudencia en 1853 en torno a la teoría del derecho; con general aplauso, dice, de la prensa. 
es "el representante perpetuo de la Nación", es "el representante del Estado", y como tal tiene autoridad legislativa "y tiene que cooperar a hacer la Constitución", incluso cree que la falta de sanción real por imperativo de la realidad en 1812 pudo influir en su corta vida. Igualmente en 1837 no interviene porque lo prohibía la C. de 1812. Pero ahora, dice, la Constitución de 1845 está vigente (murmullos ensordecedores).

En todo caso cree indudable que la Corona debe sancionar la Constitución, y más estando en vigor las partes no anuladas de 1845, como esa precisamente. Entiende que es innecesaria prevenir el modo de reformar la Constitución en el sistema monárquico constitucional: "habiendo dos Cámaras, veto real y Monarquía hereditaria, no hace falta ese medio, esa cortapisa. La garantía (de la Constitución) está en otra parte... En la diversidad de intereses de los tres Poderes". Escosura le contradice, explicando lo que es la soberanía nacional. "consiste en el derecho que ha tenido siempre, que tiene hoy y que tendrá constantemente todo el pueblo de darse el género de gobierno que más convenga a su situación y a sus necesidades" ${ }^{40}$. Contestando a Olózaga nos aclara que el modelo de Monarquía más parecido al que él propone sería la paccionada de Aragón.

Cánovas precisa más, le da la función al trono de representar a todos los ciudadanos, no sólo a los electores y a los que tienen capacidad política, puesto que no entiende ni cree en la soberanía que signifique que todos los individuos intervengan como si fuera el ágora griega, puede uno imaginar que piensa-, sino que hay un punto medio en el que cree; y todo ello sin negar, dice, la soberanía nacional. Todo el misterio está en que se acepta el principio pero la no práctica que algunos quieren hacer implícita. Explica las tres formas que entiende que hay de soberanía: la del Soberano que hace todo por sí, aquella en que interviene "el pueblo entero, desde el primero hasta el último de los ciudadanos... en el derecho electoral y en la gobernación del Estado", y por fin la que él apoya: "un sistema medio... el único verdadero y posible en la escuela monárquica constitucional, que consistía en tener un cuerpo electoral limitado, que... nombrase su representación, y que para la inmensa mayoría de la nación hubiese otra representación, y esa era para mí... (le interrumpe el presidente) ... pretendía probar, que en España por mil circunstancias la representación de esa inmensa mayoría de la Nación, desheredada por el sufragio, era el trono"41 (también plantea ya Ríos Rosas esa idea de que los votos se pueden contar o pesar, y que en él significa prestar atención a la calidad del voto más que al número; lo que luego tendrá amplio protagonismo durante la Restauración).

Escosura explica bien la cultura política moderada que refleja Ríos Rosas en su voto particular y sus explicaciones; entiende que muestra bien el "error del partido moderado", que aún reconociendo el principio de la soberanía se empeña en hacerlo inoperante. Es decir, el partido moderado "no niega ningún dogma liberal, pero jamás ha concedido la aplicación de ninguno", porque "una vez reconocido el principio, dicen, ocultémoslo, velémoslo, porque de no hacerlo así, su paliación puede tener consecuencias funestas". Es ésta una definición que se ajusta como un guante a la historia española.

40 DSCC, op. cit., Escosura el 30 de enero de 1855

41 DSCC, op. cit., Cánovas el 29 de enero de 1855 
Sancho, ante la observación de Ríos Rosas frente a la soberanía nacional, deja planteado el problema básico de la aplicación del liberalismo en España: la pelea en torno a la aceptación o no de la soberanía nacional como fundamento constitucional, independientemente de lo que luego se aplique. Se muestra lo que todos aceptan pero lo que no todos están dispuestos a sostener como fundamento de la organización política, en una especie de contradicción que define el liberalismo español:

Señores, yo creo que es una verdad que no se puede poner en duda por nadie, y mucho menos por el señor Ríos Rosas, que admite que toda potestad emana de la Nación, que la Nación es soberana, y que todos los poderes públicos nacen de la Nación. Eso entendemos y proclamamos todos, y no podía yo suponer que el Sr. Ríos Rosas se opusiera a esto. Yo no entiendo que la palabra soberanía tenga ningún otro significado en las Constituciones sino éste, que es el supremo poder, el origen de los poderes; todos emanan de la Nación y ella es la que da todos los demás poderes

Y es que, como dice Sancho no entendiendo que lo repugne Ríos Rosas porque luego lo acepta de hecho, la soberanía nacional significa "que la Nación tiene el derecho exclusivo de establecer sus leyes fundamentales, ...; y si no es eso, no sé lo que puede significar"; y eso significa, sigue haciéndolo explícito para que no quepa ninguna duda -y ahí está la cuestión central, el eje de todas las disensiones-, que la Constitución no va, como el resto de las leyes a la sanción, no necesita sanción real: "si no es una cosa convenida que la Constitución no ha de ir a la sanción de S.M., yo no sé, señores, qué es lo que está convenido. Éste es un principio convenido sobre el cual no puede haber duda". Reconoce que hay muchos que creen que ésta es un doctrina peligrosa, y él entonces aclara más su postura personal: "la soberanía popular... es un poder absoluto, omnímodo, omnipotente, sin que tenga límite" porque no hay quien se lo ponga porque el resto de los poderes están por debajo: aquí está el centro de todos los problemas del liberalismo español, excluir al Rey de la Constitución, de la organización política, porque se considera, por alguna parte de los liberales, entre los que se encuentra el propio Ríos Rosas, que el Rey, la Monarquía, forma parte de esa misma nación, pertenece, fundamenta, la constitución histórica de España, junto con las Cortes, como tendrá ocasión mucho más delante de decir varias veces y sostenerlo en la práctica el propio Cánovas que ahora se iniciaba en su vida pública pero que luego pasará a ser protagonista principal en la Restauración de la Monarquía, precisamente, tras la experiencia de la I República.

Sancho refleja como nadie en este caso, y con ocasión de la intervención de Ríos Rosas, la cuestión central del liberalismo español, la contradicción que quiso resolverse por parte del sector moderado, variando con una interpretación española de la soberanía, en la que cupiera el Rey como parte de la nación misma y su potestad. Cita Sancho a Marina, a Martínez Marina "la persona más entendida en estas materias" para decir que nunca pudo probar que "que las Cortes antiguas tenían facultades legislativas por este título". Pero además Sancho se entretiene en los significados de libertad y soberanía, en plural: "la Nación libre en el sentido verdadero -diríamos ahora actual- es la Nación que se gobierna con leyes constitucionales", y de paso define constitucional en el sentido histórico que adquirió tras las revoluciones: "es decir, la Nación que tiene divididos los Poderes, hecha su Constitución, que es la división de los Poderes". 
Pero Sancho hace algo más, y es ya definir el significado post-revolucionario -podríamos llamarlo así- del concepto de soberanía. Una vez definida como omnipotente, matiza sus significados: es omnipotente la soberanía de la nación pero no lo son sus representantes, al menos no lo son las Cortes como los elegidos por la Nación, y por ello no pueden decir "podemos hacer lo que queramos", porque "esto es un absurdo" porque la propia soberanía está por encima de las Cortes, y por encima de éstas también está el "poder electoral", "gran poder entre la Nación y las Cortes", y que es "la emanación primera de la soberanía nacional", aunque no por ello los diputados tienen mandato imperativo porque si no no serían representantes nacionales, sino sólo de su provincia, incluso sólo de sus electores -y por ello el mandato imperativo estaba prohibido en la Constitución francesa-. Además, en caso de que existiera el mandato imperativo no habría lugar a discusión alguna y en ese sentido habría que hacer lo que decía Mirabeau: "mandad el cuaderno allí, y no es menester que vaya el diputado". Así es que en esta interpretación el primer poder es la nación misma, el segundo el poder electoral y el tercero las Cortes Constituyentes. En fín, las Cortes no son omnipotentes, sólo pueden hacer la Constitución política, no cambiar la constitución social.

Y con eso llega a la cuestión central: ¿podrían estas Cortes quitar el trono? No contesta, sólo cita un dato, y es que se votó por 208 votos contra 21 a la reina y su dinastía, $\mathrm{y}$, añade, los que no piensan así no se atrevieron a plantearlo en los colegios electorales porque "no hubieran sido elegidos" añade contundente, entendiendo que forma parte de la constitución social española. Y todo ello para intentar convencer de que la soberanía nacional no es tan temible como algunos la presentan, porque en la práctica, en sus representantes tiene muchas limitaciones. Entiende que no hay ningún revolucionario en estas Cortes y lo que hay es una salida al desgobierno, al abuso de los gobiernos y no se encontró medio para evitarlo. Si hay que optar entre el despotismo y la revolución, añadiendo que ya no es ni joven ni inexperto, no puede optar sino por la revolución.

Alonso va más allá y relaciona la teoría de Ríos Rosas y de Cánovas con Constant y Royer collard, es decir con los llamados doctrinaRíos y, en realidad, con la doctrina post-revolucionaria, adaptadora de los principios revolucionaRíos a la práctica política. Dice que también ellos negaron la soberanía nacional porque era la soberanía de las fuerzas ciegas, de la fuerza y optaron por la "soberanía de la razón... de la libertad... de la verdad.... Del derecho", y entiende que pertenecen a una escuela que podría denominarse "de derecho absoluto" pero, dice, "la historia es un almacén donde todos encuentran a placer lo que buscan. El escepticismo, el eclecticismo, todas acomodan los hechos a su manera"42

Pero Olózaga dice más frente a la teoría de Ríos Rosas, dice que lo suyo es una defensa disfrazada del derecho divino de los Reyes "fundándole (sic) en la tradición, en el tiempo, en la sucesión de los siglos, ... eso también es el derecho divino, tan absurdo como cuando se presenta en su forma desnuda y ridícula"; la teoría "de la tradición, de la antigüedad y prescripción inmemorial" es "una teoría disimulada del derecho divino". Sí admite que se profesa "ese gran principio", "bandera del partido progresista, tal como se consignó en la Constitución de 1812" aunque "con menos filosofía y

42 DSCC, cit., Alonso el 29 de enero de 1855. El resto de intervenciones son también de este día sin necesidad de consignarlo en cada una de ellas 
precisión" de la que formularon "los enciclopedistas" en el siglo anterior. Olózaga en estas fechas defiende decididamente "el derecho único y exclusivo (de las Cortes) de decretar y sancionar la Constitución del Estado" y vuelve a interpretar su propia obra de 1837 asegurando que si bien no hubo medio específico para su reforma "dejamos bien determinado el medio único para reformarla, que es el que la reformase cuando lo quisiese la Nación por las Cortes que decretasen y sancionasen su reforma"

Cierto que a la vez reconoce "en derecho todo lo podemos, pero el principio que no tiene en su inteligencia limitación alguna, tiene la única del principio mismo, que es la voluntad nacional. Nosotros no podemos hoy destruir la Monarquía en España; es tan antigua como su historia conocida". Reconoce también con Ríos Rosas que "no quisiera que fuesen muy frecuentes las discusiones de esta especie; no quisiera que se proclamasen aquí todos los días ciertos principios, de cuya aplicación mal entendida pueden resultar males; no quisiera que se tocase a los cimientos del edificio social... es exponerse a que pueda arruinarse... pues si a menudo se anda en las raíces, el árbol se secará"

Con Ríos Rosas, además de Cánovas está Nocedal ${ }^{43}$, con la fuerza que les da ser firmes enemigos del sufragio universal, como los progresistas, mientras lo asocian a la Soberanía Nacional. Por eso pregunta este político "qué entendéis por Nación?" y los coloca entre la espada demócrata y la pared conservadora para concluir, no sin acierto, que "estáis vendidos". Es cuando definitivamente se defiende la soberanía de los poderes constituidos, frente a la nacional; la "omnipotencia parlamentaria frente a frente de la soberanía nacional como un correctivo a ella" "ese es el dogma de los partidos liberales" "la omnipotencia parlamentaria que reside en las Cortes con el Rey"

Cierto que Nocedal va más allá, dice que él en realidad suprimiría la base primera porque no cree que deba figurar en la Constitución la soberanía nacional, pero lo convenció Ríos Rosas que, dice, "no ha podido ser ni más elocuente, ni más elevada, ni más digna, atrayéndose en esa sesión, como en todas, la atención y la admiración de la Asamblea, como siempre que levanta su voz elocuentísima mi digno amigo el Sr. Ríos Rosas"

El afán de los "historicistas" es partir de la tradición, que dicen que en España no se sigue, aunque pongan el ejemplo de la revolución inglesa como tradicional y conservadora-olvidando que se mató al Rey, hubo guerra civil, una dictadura y una república-; es el argumento de Nocedal que entiende que se sostiene en Inglaterra por ese carácter tradicional y conservador de su revolución del XVII -que queda contradicho ya por la historiografía actual-.

\section{Ríos Rosas y la Monarquía}

Ríos Rosas tiene ocasión de manifestar sus opiniones todavía en otro proceso constituyente, el de 1869 , y de nuevo desde la comisión constituyente, acompañado entre otros por Posada Herrera, Vega de Armijo, Silvela, Moret como Secretario o Becerra, siendo Olózaga el presidente de la misma. En este proceso, es de nuevo Salustiano

43 DSCC, cit., Nocedal el 1 de febrero de 1855 
Olózaga entre los progresistas, el que inclina la balanza hacia las soluciones conservadoras, como sucedió ya en 1836 y 1854 . Es Castelar ${ }^{44}$ con buen criterio quien hace esa acusación al ya maduro político que se encontraba situado entre los demócratas y las firmes convicciones conservadoras, dice, que se notan en "el proyecto constitucional, que lleva el sello del gran carácter que distingue a muchos de sus individuos". Entre estos individuos, sin duda, la fuerza de Ríos Rosas.

Pero en esta ocasión Ríos Rosas muestra mayor avance ideológico que el conservador Cánovas, al que ataca; deplora la "prevención" constante que éste pide; parece también capaz de aprender de la historia más inmediata: "no nos acomoda el sistema de prevenciones; no estamos por un sistema que ha arruinado la libertad, que ha traído la crisis pasada y que ha acabado con ese trono que allí estaba". Deplora asímismo "el vicio de la centralización excesiva" "hay que optar entre la centralización y el régimen constitucional". Asocia "la centralización, el absolutismo, el despotismo, llámese como se quiera", y lo une a la corrupción. Sin embargo, sobre la federación dice que "la voluntad sirve para muchas cosas en el mundo: no sirve para improvisar formas de gobierno" (20 de mayo de 1869 ). Éste es un tema que merecería estudio en profundidad por quienes ahora están trabajando sobre este político, como el profesor Ruiz Cañestro, porque evidentemente hay disparidad de criteRíos entre lo que dice en el Bienio respecto al poder de los Alcaldes, que deplora, y como juzga en estos momentos la centralización. La idea de centralización / federación está íntimamente ligada con la forma de gobierno, con la cultura política que diseña del Estado Constitucional.

De Cánovas, su "correligionario", recuerda, le asombra algo profundamente y le pide confirmación de haberlo oído bien; y es que Canovas decía que se desprestigiaba el Senado porque se hacía pasar primero los presupuestos por el Congreso que además prevalecía en caso de disensión entre las Cámaras. No recuerdo haber encontrado algo parecido en Cánovas durante la Restauración, quizá influido por este asombro de Ríos Rosas que tuvo que hacerle un análisis histórico-constitucional del origen - desde Inglaterra- y sentido de esa práctica política inexcusable en toda la historia constitucional y quizá nunca discutida "porque esta disposición en ese sentido no es peculiar de la Constitución de España, sino que existe en las Constituciones europeas y se ha trasladado a todas el sentido de la Constitución inglesa". Le recuerda la propia tradición española, incluso en 1845 "quedando implícita la interpretación del 37" para asombrarse de que "nadie ha sido tan escrupuloso ni tan celoso de la autoridad moral y del prestigio del Senado como el Sr. Canovas".

Es más, el asombro se muestra multiplicado, y tiene ocasión de dar una lección a Cánovas que calificaría de histórica pues afecta al fondo mismo de todo el sistema constitucional:

"pero la ley de presupuestos es una ley necesaria, absolutamente necesaria es menester que haya ley de presupuestos todos los años; no se puede vivir sin ley de presupuestos... se ha optado por el medio de que sea ley aquello que haya votado uno de los Cuerpos: pudiera haberse optado que fuese ley aquello que hubiera votado el Senado: para esto había razones en pro y razones en contra, y se ha optado por lo que

44 Diario de Sesiones. Congreso, legislatura 1869-1871 (DSC 1869-1871). Castelar el 9 de abril de 1869. 
vote el Congreso. Esto es claro, elemental, rudimentario; no sé como a una persona de la inteligencia, del talento, de la capacidad, de la instrucción del Sr. Canovas haya podido ocultársele".

No puede evitarlo, lo juzga, y le acusa de ligereza en sus razonamientos, "son ligerezas pesadas" 45

Frente a Castelar ofrece culto a la propiedad, igual "individual" que "colectiva", en referencia a los bienes de la iglesia, que según él es sagrada también, y ésa es la razón, recuerda, de indemnizarla y pagarle el tributo de culto y clero.

Tiene ocasión entonces de definir claramente los tipos de monarquía y cuál es su preferencia. De las dos que nos interesan, la del pacto, la paccionada entre el Rey y el pueblo, en sus palabras, que encuentra en Inglaterra y Aragón "y quizá de Navarra y quizá de Castilla"; y la de la soberanía nacional "en el que se reconoce plenamente la soberanía de la Nación... del Estado, el poder original, el poder primario uno y único que es el Estado... todos los poderes emanan del Estado y se regulan por el Estado", lo que nos sirve para confirmar, además, que ya distingue el poder Ejecutivo del Poder Moderador, como era propio de la doctrina constitucional aunque las Constituciones no lo escribieran. Efectivamente, tras relatar los tres poderes que proceden del Estado, equiparando este término a Nación, continúa: "Y después de éste hay un poder que representa la unidad del Estado, poder que sirve de vínculo, respetando su integridad y su independencia, a todos los demás poderes; un poder que dirime en primera instancia las contiendas que se suscitan entre los demás poderes, por ejemplo, entre el poder legislativo y el poder ejecutivo; este poder, poder armónico, poder mediador, poder inspector y poder moderador, se crea de un modo en unos Estados libres, y en otros Estados libres se crea de otro modo". Se adelanta así a la definición del poder armónico del primer catedrático de Derecho Constitucional, Santamaría de Paredes, profesor después de Alfonso XIII.

Esa diferencia de organizar el poder moderador es la que hay entre Monarquía y República, es la forma dice, bastante equivocadamente, de los Estados Unidos -donde no existe tal poder moderador porque el presidente es el poder ejecutivo pleno-. Entiende que ha de ser uno, imparcial, neutral, impersonal "y no puede tener opinión propia", "ni puede ser la hechura de un solo partido". Lo que sí hace estupendamente es explicar la funcionalidad de la Monarquía en este modelo post-revolucionario, para ejercer el poder moderador, para que ese Poder tenga esas características impersonales e imparciales, que se contradicen con el sistema de elección por partidos. Está adelantando el problema de las Repúblicas que se extenderán por Europa bajo el modelo de la III francesa, las repúblicas parlamentarias, que heredan un modelo, el parlamentarismo en sentido estricto diseñado para la Monarquía y el poder impersonal. Tiene el mérito de adelantarse a lo que vendrá, pero comete el error de poner como ejemplo a la única República no parlamentaria de referencia, los Estados Unidos. Le sirve para criticar "la política personal de los presidentes" y sus choques con las Cámaras, unas veces para que éstas queden anuladas como con Jackson, otras para que éstas anulen al presidente, como a Jhonson.

45 DSC, 1869-1871, Ríos Rosas el 9 de abril de 1869 
Su conclusión a favor de la Monarquías es clara: "En las monarquias, el gobierno personal es un accidente, en las repúblicas es una necesidad", y es que, continúa, "la herencia tiene de bueno que puede existir, y existe perfectamente en un Estado libre... si se hace una condición exclusivamente del derecho político, la herencia pierde todos sus inconvenientes y conserva todas sus ventajas": "la autoridad que no espera la reelección, la autoridad que no tiene que corromper para ser reelegida, esa autoridad es más natural, esa autoridad es más imparcial, esa autoridad es más impersonal que cualquiera otra" y la confirmación la encuentra en la historia, en la falta de gobierno personal en Inglaterra, o desde hace veinte años en Bélgica, en Italia, en Portugal "sin agravio ninguno a la soberanía nacional". Luego nos explica las funciones, hoy bien conocidas al menos por los analistas, del poder moderador que se pueden resumir en la capacidad de suspender cualquiera de los poderes.

Vemos, pues, evolucionar a Ríos Rosas, y si antes se había decantado por la Monarquía paccionada de Inglaterra y Aragón, ahora, más perfilado el poder moderador, el armónico, que parece haber estudiado con detenimiento, entiende que ni siquiera hace falta que el Rey tenga un tercio del poder legislativo, que implica esa expresión del Rey en Parlamento en Inglaterra, o el Rey y el reino en Aragón. Ahora reconoce que "hay que distinguir y mucho entre el poder ejecutivo y el poder real", y de nuevo para contestar a Cánovas y sus temores de desprestigio de ciertos poderes, como el del Senado o el del Rey: "nosotros no le hemos quitado nada de lo que necesita". Ante la acusación de transigir, dice que sólo tuvo que ceder, que transigir con la declaración de derechos individuales y con el sufragio universal, nada más. Pero con éste último no tuvo más que ser consecuente, puesto que por él fue elegido, igual que Cánovas, que de ese modo lo aceptó. La historia, la práctica también le sirve para eso, al fin, dice, el sufragio universal llevó a las Cortes una mayoría monárquica.

De ese modo llegó el enfrentamiento directo entre dos correligionaRíos, uno que venía del pasado, que evolucionó con los tiempos, y otro que llenaría el futuro, que quizá tuvo que evolucionar también, pero que en este momento representaba una versión más conservadora, más cerrada a la realidad que el propio diputado histórico, Ríos Rosas. Se criticó mucho a Cánovas los modos"la forma con que S.S. usaba de ese derecho" (hablando de infeliz obra, de anarquía que Ríos Rosas le recuerda una y otra vez e incluso Cánovas niega) Cierto que éste venía de la Unión Liberal, como reconoce Cánovas ${ }^{46}$, que se dedica a matizar las cuestiones del Poder Moderador. Fundamentalmente que todo sería correcto si se hubiera hecho como en la Constitución portuguesa, consignar ese cuarto poder, de lo contrario, dice no le sirve el razonamiento. Cierto que cuando él mismo tuvo que elaborar una Constitución, en 1876, tampoco consignó el cuarto poder, lo que no evitó que siguiera esa doctrina. Es decir, siguió la doctrina de Ríos Rosas que el mismo día le mostró:"que si ya tiene el rey, por los términos contenidos en el proyecto, el carácter y las funciones de poder moderador; que si tiene ese carácter y esas funciones, importa poco o nada que en el epígrafe del título se le designe con el nombre de poder moderador. Ésta es cuestión de forma... no afecta en esencia a la cuestión". La razón, dice, son las diferentes teorías existentes "acerca de la naturaleza del poder real" por lo que es preferible

46 DSC, 1869-1871, Cánovas el 12 de abril de 1869 
"prescindir de toda consideración y de de toda exposición teórica", y añade "es el método de todas las Constituciones españolas" -sin mencionar la del 45, pues pasa de la del 37 a la del 56-.

Ríos Rosas, además, nos da un dato de gran relieve en nuestra historia constitucional, para el estudio de las culturas políticas liberales. En un tema de tanta trascendencia y significativo en la evolución de la construcción del Estado Contemporáneo como la evolución de los poderes, como la situación de la Monarquía en el constitucionalismo, nos informa en su discurso del 12 de abril que se quitó el término "poder Ejecutivo" para sustituirlo por el de Rey. Es un dato precioso que nos indica ya el conflicto constitucional respecto a la posición del Rey. Todavía titular del poder Ejecutivo, la doctrina lo aleja de esa posición para situarlo en un poder diferente, pero no se incluye en los textos. Así es que hay que hilar fino para sostener ese conflicto, esa contradicción entre teoría y práctica política que no se resolvió hasta la nueva época constituyente del siglo XX, en nuestro caso en la Constitución actual. El diputado nos informa de que fue "una omisión o una errata" de "la misma persona que hizo el bosquejo", que "empleó constantemnte en el texto la frase de Poder Ejecutivo, que se corrigió, dice, después, pero las prisas había impedido que lo quitaran del epígrafe, errata ya corregida.

Más adelante lo dice claro: "el rey constitucional no es responsable porque como pode ejecutivo no hace nada, absolutamente nada; porque todo lo hacen los ministros responsables y justiciables; él no hace nada; y el rey constitucional no es responsable como poder mediador, porque aun en esas circunstancias obra con la cooperación de los ministros responsables. El que no hace nada por sí, no es libre, no es responsable por ningún criterio penal, mucho menos por el criterio amplio de la política. Así la responsabilidad el monarca no es una ficción; pero la responsabilidad del presidente en cambio es una mentira" 47

Pero además Ríos Rosas muestra su distancia de la política del justo medio de Cánovas, y lo hace en ese tema trascendental, en el concepto que tienen del poder real. Mientras Cánovas, que "considera de muy distinto modo que yo el poder real", "cree que se compone de fragmentos de las facultades de los demás poderes"; él entiende que "el poder real es diferente de los demás poderes", es un poder propio, armónico, moderador, diferente a los otros tres, a los poderes clásicos, siguiendo claramente la doctrina de Constant. La de Cánovas, dice, es "la doctrina de los hombres del justo medio, es la teoría de los hombres del derecho divino, es la teoría de los hombres del derecho patrimonial". Para él, sin embargo, el poder armónico funciona igual en una monarquía que en una república, "como solo un poder, diferente de los demás poderes, uno en sí mismo, con cualidades internas, diferentes de las que tienen los demás poderes del Estado".

47 Ríos Rosas, 20 de mayo de 1869 


\section{Fuentes y Bibliografía}

ÁLVAREZ ALONSO, C., "Un Rey, una Ley, una Religión (goticismo y constitución histórica en el debate constitucional gaditano)", Historia Constitucional. Revista Electrónica, $\mathrm{n}^{\mathrm{o}} 1$ (junio 2000).

ARTOLA, M., La España de Fernando VII, Madrid, Espasa Calpe, 1999.

Archives Parlamentaires. Asemblée nationale. Paris (APP.AN).

CORONAS GONZÁLEZ, S.M., "El pensamiento Constitucional de Jovellanos", en Historia Constitucional. Revista Electrónica , $\mathrm{n}^{\circ} 1$, junio 2000

Diario de Sesiones de las Cortes Generales y Extraordinarias (DSCGE), 1810-1812

Diario de Sesiones del Congreso, Cortes Constituyentes (DSC, CC), 1854-1855

Diario de Sesiones del Congreso, legislatura 1869-1871 (DSC 1869-1871)

FERNÁNDEZ SARASOLA, I., Poder y libertad. Los orígenes de la responsabilidad del Ejecutivo en España (1808-1823), Madrid, Centro de Estudios Políticos y Constitucionales, 2001.

FERNÁNDEZ SARASOLA, I., La Constitución española de 1812 y su proyección europea e iberoamericana, Alicante, Biblioteca Virtual Miguel de Cervantes, 2004.

FURET, F., HALÉVY, R., La Monarchie Républicaine. La Constitution de 1791. Fayard, 1996.

JOURDAN, A., La Révolution, une exception française?, Paris, Flammarion, 2004.

JOVELLANOS, Melchor Gaspar de, Memoria en defensa de la Junta Central, puede consultarse en la Biblioteca Virtual Cervantes: http://www.cervantesvirtual.com/ servlet/SirveObras/12048065338088290754624/p0000001.htm\#I_2_

La Costituzione della Repubblica nei lavori preparatori della Assemblea Costituente (AS,CD). Archivio Storico. Camera dei Deputati.

LARIO, A., "Del liberalismo revolucionario al liberalismo post-revolucionario en España. El triunfo final del camino inglés", Espacio, Tiempo y Forma, V, $\mathrm{n}^{\circ} 17$ (2006).

LARIO, A., "El modelo liberal español", en Revista de Estudios Políticos, n 122 (2003).

LARIO, A., "La Monarquía del Liberalismo a la Democracia", en LARIO, A. (ed.), Monarquía y República en la España Contemporánea, Madrid, UNED- Biblioteca Nueva, 2007.

LARIO, A. (ed), Monarquía y República en la España Contemporánea, Madrid, UNED / Biblioteca Nueva, 2007.

LARIO, A., "La Monarquía Constitucional. Teoría y práctica política", en TUSELL, J., LARIO, A. y PORTERO, F. (eds), La Corona en la historia de España, Madrid, Biblioteca Nueva, 2003. 
LARIO, A., "La Monarquía en España y la construcción del Estado Contemporáneo", en LANDAVAZO, M. A. (ed.), Experiencias monárquicas y republicanas en Hispanoamérica, siglos XIX y XX, México, Porrúa / Universidad Michoacana de San Nicolás de Hidalgo. 2009.

MARTÍNEZ MARINA, Francisco Xavier, Discurso sobre el origen de la Monarquía y sobre la naturaleza del gobierno Español (1813), puede verse en la Biblioteca Virtual Cervantes: http://www.cervantesvirtual.com/servlet/SirveObras/57960620216137506322202/index.htm

MORENO ALONSO, M., La forja del Liberalismo en España. Los amigos españoles de Lord Holland 1793-1840, Madrid, Congreso de los Diputados, 1997.

PORTILLO VALDÉS, J. M., Revolución de nación. Orígenes de la cultura constitucional en España, 1780-1812, Madrid, CEPyC, 2000.

POSADA, A., La reforma constitucional, Madrid, 1931.

SÁNCHEZ GARCÍA, R., Alcalá Galiano y el liberalismo español, Madrid, CEPyC, 2005.

VARELA, J., Jovellanos, Madrid, Alianza Universidad, 1988.

VARELA SUANZES, J., "Sistema de Gobierno y partidos políticos en el pensamiento constitucional británico durante el último tercio del siglo XVIII (de Blackstone a Paley)", en Historia Constitucional. Revista Electrónica, nº 1, 2000. 